\title{
A LC/MS-MS Guided Isolation of Laccaic Acid-A: A Potent Antimicrobial Agent
}

\author{
Suddhasattya Dey, Manik Ghosh* \\ Department of Pharmaceutical Sciences and Technology, Birla Institute of Technology, Mesra, Ranchi-835215, Jharkhand, INDIA.
}

\begin{abstract}
Background: Lac is traditionally used as a dye because of its coloring properties and it is obtained from Laccifer lacca Kerr. Now a days, it is widely used in food and coloring industry. Purpose: To evaluate the antioxidant, antimicrobial activity of different extracts along with identification of active constituents present in it. Methods: Antioxidant activity was performed by DPPH, reducing power and hydrogen peroxide scavenging activity, whereas antimicrobial activity was performed by well diffusion method to evaluate the antimicrobial potential of chloroform, ethyl acetate, methanol and water extracts. Based on the most potent activity of the extracts were run in LC-MS/MS to identify the active constituent from it. Results: Ethyl acetate and methanol extracts were found to have most potent antioxidant activity with more than $50 \%$ inhibition at a concentration of $16 \mu \mathrm{g} / \mathrm{ml}$ where all the three methods when compared with ascorbic acid as standard. Antimicrobial activity was also found to be potent for ethyl acetate and methanol extract having a zone of inhibition of $15 \mathrm{~mm}$ and $18 \mathrm{~mm}$ for $E$. coli and $S$. aureus respectively. Finally, ethyl acetate and methanol extracts were processed for an effective LC-MS/MS run to identify the active constituent as laccaic acid-A in both the extract. Conclusion: Laccaic acid $A$ is identified as the main constituent present in ethyl acetate and methanol fractions responsible for the antioxidant and antimicrobial activity.
\end{abstract}

Key words: Laccifer lacca Kerr., DPPH, Reducing power, Hydrogen peroxide, Antimicrobial assay, LC-MS/MS, Laccaic acid-A.

\section{INTRODUCTION}

Lac is a natural polymer (resinous exudation) from the female scale insect. Laccifer lacca Kerr. Lac is generally obtained by crushing, sieving and washing of stick-lac. Resin is the major constituent of lac. Lac resin is a complex straight chain hydroxyl fatty acids such as butolic acid, aleuritic acid, jalaric acid, shellolic acid, laccishellolic acid etc having $\mathrm{C}-14$ to $\mathrm{C}-18$ carbon chain. Other than resin there are other components of lac. The percentage wise composition of lac (data adopted from Indian Lac Research Institute, ILRI) is lac resin $68 \%$, lac wax $6 \%$, lac dye $1-2 \%$ and others $25 \%{ }^{1}$ Lac dye is a combination of anthraquinone derivatives consists of laccaic acids. Lac has multipurpose application in different fields such as military, electric appliance, printing ink, leather, plastic, metallurgy, machinery, woodworking, food, medicine, etc. ${ }^{2}$ Though lac has multipurpose use in the various industries recently it has proven its anticancer activity in MCF-7 breast cancer cell lines. It inhibits direct DNA competitive inhibitor of DNA methyl transferase I by altering the expression of the methylated gene in MCF- $7 .^{3}$ The result of DPPH assay indicates the higher $\mathrm{EC}_{50}$ value of lac dye than the $\mathrm{EC}_{50}$ value of aluminum lake. ${ }^{4} \mathrm{Lac}$ is widely used for food coloring and also acts as a protease inhibitor in terms of both auto activations of PHBP (Plasma Hyaluronan-Binding Protein) proenzyme $\left(\mathrm{IC}_{50}=0.35-0.55 \mathrm{~g} / \mathrm{ml}\right)$ and the catalytic activity of the active enzyme $\left(\mathrm{IC}_{50}=\right.$ $1.1 \mathrm{~g} / \mathrm{ml}) .^{5}$ Lac extract has been analyzed by a high-speed counter-current chromatography for the isolation of laccaic acids $A$, $\mathrm{B}, \mathrm{C}$ and $\mathrm{E}$ the major chromophores
Submission Date: 03-05-2018; Revision Date: 14-08-2018; Accepted Date: 23-10-2018

DOI: 10.5530/ijper.52.4s.109 Correspondence: Dr. Manik Ghosh, Department of Pharmaceutical Sciences and Technology, Birla Institute of Technology, Mesra, Ranchi-835215, Jharkhand, INDIA. Phone no: $+91-9430360991$ E-mail: manik@bitmesra. ac.in

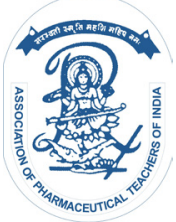

www.ijper.org 
present in lac-dye. ${ }^{6}$ For the identification of laccaic acids in jellies and stick lac samples an ESI LC-MS/MS method, has been reported using a volatile mobile phase acetylacetone. ${ }^{7}$ Laccaic acids A, B and E were detected in all lac color products and were analyzed using HPLC comprising of reverse phase C-18 column with a PDA detector set at $280 \mathrm{~nm}$ and $490 \mathrm{~nm} .{ }^{8}$ An analytical method was developed for the toxicity studies of lac color in diet and feces of rat. ${ }^{9}$ Laccaic acid A was isolated using cellulose column, preparative paper chromatography and characterized by using IR and UV-Vis. ${ }^{10}$ The pKa of laccaic acid was reported to be 4.4 and $6.5{ }^{11}$ Isolation of laccaic acid $\mathrm{C}$ was performed using cellulose column as a major fraction and laccaic acid $\mathrm{E}$ as a minor fraction, both were reported to possess similar properties like laccaic acid $A$ and $B$ but differs in $\alpha$ - amino acid as a side chain. ${ }^{12}$ Using silica gel column and acetone as an eluent isolation of laccaic acid $\mathrm{D}$ was performed from rangini stick lac. ${ }^{13}$ Laccaic acid B was isolated from the polyamide column as a minor fraction and characterized using UV and IR. They also reported the presence of chelated quinine group in laccaic acid B. ${ }^{14}$ From recent literature study, it was found that a HPLC-DAD-MS analysis of colorant and resinous components of lac-dye was performed. The authors reported that a comparative study was performed for the identification of laccaic acid $A$, laccaic acid B, laccaic acid C and laccaic acid E present in Kerria and Paratachardina genera. ${ }^{15}$ However, there was no information available regarding antibacterial activity of lac dye from Laccifer lacca, Thus, our present work focuses on the antibacterial activity of different extracts of Laccifer lacca and evaluation of antioxidant activities of these extracts by different methods. Further study is also undertaken to identify the active component present in the bio-active fractions by LC-MS/MS. The antimicrobial activity is performed employing well diffusion assay by determining the zone of inhibition.

\section{METHODS AND MATERIALS}

\section{Chemicals and reagents}

All the chemicals and reagents used were of analytical grade. Water was purified by the Milli Q water purification system (Millipore, Milford, MA, USA). Methanol, petroleum ether $60-80^{\circ} \mathrm{C}$, chloroform, ethyl acetate and formic acid used were of AR Grade purchased from Ranchem private limited. Syringe filters having the pore size of $0.22 \mu \mathrm{m}$ were purchased from Merck, Mumbai. Lac-dye was provided by Indian Institute of Natural Resins and Gums, IINRG, Ranchi, Jharkhand, India. DPPH (2, 2-diphenyl-1-picrylhydrazyl), hydrogen peroxide, potassium ferricyanide $\left(\mathrm{K}_{3}\left[\mathrm{Fe}(\mathrm{CN})_{6}\right)\right.$, phosphate buffer $\left(\mathrm{KH}_{2} \mathrm{Po}_{4}\right)$, trichloroacetic acid, ferric chloride $\left(\mathrm{FeCl}_{3}\right)$ and ascorbic acid used were purchased from Sigma, U.S.A. Acetonitrile, water and methanol used were of LC-MS grade purchased from Fisher Scientific (Loughborough, Leicestershire, UK). The Instrument used for the present study was UV-VIS spectrophotometer Model No 2450 and the data acquisition was carried out by UV probe 2.3 version. All the bacterial strains were procured from the Microbial Type Culture Collection and Gene Bank, an International Depository Authority, Chandigarh, India, maintained in nutrient broth at $-20^{\circ} \mathrm{C}$.

\section{Preparation of Technical grade and sample preparation of lac dye}

\section{Technical grade}

Stick lac was washed with water then acidified with $\mathrm{HCl}(0.1 \%$ on the vol. of water $)$ and the supernatant liquor was collected by filtration. Calcium carbonate or quicklime was used to treat the mixed filtrate until the liquor becomes colorless. By the help of filtration calcium salt of lac dye that has separated out was gathered and washed repeatedly with water. The calcium salt of lac dye (the cold suspension) in water was kept for a week after acidification at room temperature until all the dye was crystallized. Later it was washed, filtered and dried out (approx. yield was found to be $0.5 \%$ weight of stick lac). Net dye content was approximately 80-90\% but it depends on the quality and age of stick lac. ${ }^{16}$

\section{Sample Preparation}

Technical grade lac was obtained as a powder. Successive fractionation was done, starting from a non-polar solvent to the polar solvents. Five grams of lac was added to $50 \mathrm{ml}$ volumetric flask containing $50 \mathrm{ml}$ of petroleum ether $\left(60^{\circ}-80^{\circ} \mathrm{C}\right)$ and allowed for ultrasonication for $10 \mathrm{~min}$ at a of temperature $40^{\circ} \mathrm{C}$. Petroleum ether solution containing lac was transferred to a $15 \mathrm{ml}$ centrifuge tube, equally distributed in 5 centrifuge tubes, centrifuged for about $10 \mathrm{~min}$ at $5000 \mathrm{rpm}$. The clear supernatant liquid was collected in petri-dishes and allowed to evaporate. The lac dye which has settled down after centrifugation in the centrifuge tubes were collected and dissolved in $50 \mathrm{ml}$ volumetric flask containing chloroform. Further, the solution was subjected to ultrasonication for $10 \mathrm{~min}$ at a temperature of $40^{\circ} \mathrm{C}$. Similarly, this procedure was repeated for ethyl acetate, methanol and water for the preparation of ethyl acetate, methanol and a water fraction. Total three sets of fractions were prepared, chloroform $(\mathrm{C})$, ethyl acetate (EA), methanol (M) and water (W) respectively. Fractionation with petroleum ether was mainly done for defatting pur- 
pose to remove the unwanted oils and unsaturated fatty acids from the samples.

\section{Assessment of extracts of lac dye for antioxidant activity \\ DPPH scavenging activity}

The DPPH radical scavenging activities of the different extracts were estimated by 2, 2-diphenyl-1-picrylhydrazyl (DPPH) method as illustrated by Miliauskas et al. ${ }^{17}$ The Methanolic solution of $0.1 \mathrm{mM} \mathrm{DPPH}$ was prepared. Samples with different concentrations $(4,8,12,16$ and $20 \mu \mathrm{g} / \mathrm{ml}$ ) were made in same solvent. Ascorbic acid was taken as a quality standard of different concentrations $(4,8,12,16$ and $20 \mu \mathrm{g} / \mathrm{ml})$ for all methods of antioxidant assay. The reaction was commenced by adding $1 \mathrm{ml}$ of DPPH solution to the $3 \mathrm{ml}$ of standard or different extracts (aqueous, methanol, ethyl acetate and chloroform) in methanol of various concentrations. The reaction mixture was vigorously agitated and kept it for half an hour in a dark place at room temperature till the completion of the reaction. Absorbance was measured at a wavelength of $517 \mathrm{~nm}$ using an ultraviolet spectrophotometer.

$\%$ of DPPH scavenging activity is $=\mathrm{A}_{\text {control }}-\mathrm{A}_{\text {sample }} /$ $\mathrm{A}_{\text {control }} \times 100\left(\mathrm{~A}_{\text {control }}=\right.$ absorbance of control reaction,

$\mathrm{A}_{\text {sample }}=$ absorbance in the presence of standard or sample).

\section{Reducing power assay}

The reducing power assay for the different extracts of lac was evaluated according to the method of Jayanthi and Lalitha with little alteration. ${ }^{18}$ Samples with different concentrations $(4,8,12,16$ and $20 \mu \mathrm{g} / \mathrm{ml})$ were made in mili-Q water. One $\mathrm{ml}$ of sample solution assorted with $\mathrm{KH}_{2} \mathrm{Po}_{4}$ buffer $2.5 \mathrm{ml}\left(0.2 \mathrm{M}, \mathrm{pH}\right.$ 6.6) and $\mathrm{K}_{3}[\mathrm{Fe}$ $\left.(\mathrm{CN})_{6}\right] 2.5 \mathrm{ml}$. The reaction blend was retained for 20 min at a temperature of $50^{\circ} \mathrm{C}$. The reaction mixture was allowed to cool, then $2.5 \mathrm{ml}$ of $10 \%$ trichloroacetic acid was added and centrifuged at $2000 \mathrm{rpm}$ for $10 \mathrm{~min}$. The upper layer of $2.5 \mathrm{ml}$ was taken to it $2.5 \mathrm{ml}$ of mili-Q water and $0.5 \mathrm{ml}$ of $\mathrm{FeCl}_{3}$ solution $(0.1 \%)$ freshly prepared was added. Absorbance was recorded at $700 \mathrm{~nm}$ using an ultraviolet spectrophotometer. In a similar way, control was prepared without the samples. Ascorbic acid was taken as the standard of various concentrations as mentioned above. Samples were analyzed and the data were presented as percentage inhibition. Increase in the reducing power of extracts at different concentrations indicates enhance in absorbance of the reaction blend.
$\%$ of reducing power $=\mathrm{A}_{\text {control }}-\mathrm{A}_{\text {sample }} / \mathrm{A}_{\text {control }} \times 100$ $\left(\mathrm{A}_{\text {control }}=\right.$ absorbance of control reaction, $\mathrm{A}_{\text {sample }}=$ absorbance in the presence of standard or sample).

\section{Hydrogen peroxide assay}

The hydrogen peroxide scavenging assay has been carried out as stated by Ruch et al. with little modification. ${ }^{19}$ Two molar (2 M) of hydrogen peroxide solution was freshly prepared in phosphate buffer $\left(\mathrm{KH}_{2} \mathrm{Po}_{4}\right)$ with a $\mathrm{pH}$ of $7.40(0.2 \mathrm{M})$. Different extracts of various concentrations $(4,8,12,16$ and $20 \mu \mathrm{g} / \mathrm{ml})$ were made readily in mili-Q water. An amount of $2.5 \mathrm{ml}$ hydrogen peroxide in phosphate buffer was mixed with $1.5 \mathrm{ml}$ of extract and standard. The blend was allowed to mix and vortexed then incubated for $10 \mathrm{~min}$ in a dark place. Absorbance was measured at $230 \mathrm{~nm}$, after $10 \mathrm{~min}$ of incubation. Ascorbic acid was taken as the standard of various concentrations as mentioned above. Phosphate buffer without $\mathrm{H}_{2} \mathrm{O}_{2}$ served as a blank. The percentage of hydrogen peroxide scavenging activity was measured from the below-mentioned formula

$\%$ of hydrogen peroxide $=\mathrm{A}_{\text {control }}-\mathrm{A}_{\text {sample }} / \mathrm{A}_{\text {control }} \times$ 100 (Where $\mathrm{A}_{\text {control }}=$ absorbance of control reaction,

$\mathrm{A}_{\text {sample }}=$ absorbance in the presence of standard or sample)

\section{Assessment of extracts of lac dye for antimicrobial activity}

\section{Antimicrobial activity}

In the present study, the test microbe used for the antimicrobial studies were Gram-negative bacteria Escherichia coli (MTCC-739) and Gram-positive bacteria Staphylococcus aureus (MTCC-3160). Three hundred milliliter of each stock-culture was added to $3 \mathrm{ml}$ of nutrient broth. ${ }^{20}$ Overnight cultures were kept for $24 \mathrm{~h}$ at $37^{\circ} \mathrm{C}$. After $24 \mathrm{~h}$ of incubation, bacterial suspension (inoculum) was diluted with a sterile physiological solution, to make a final cell concentration of $10^{5} \mathrm{CFU} / \mathrm{mL}$.

\section{Bacterial media}

Sterilization of Muller-Hinton Agar (MHA) media mixed with distilled water was performed in an autoclave at 15 $\mathrm{lb}$ pressure for $15 \mathrm{~min}$. In the petri dishes, sterile media was poured and allowed it to solidify. The bacterial inoculum $\left(10^{5}\right.$ cells $\left./ \mathrm{ml}\right)$ was equally distributed by a sterile cotton swab on a sterile petridish MHA. The sterilized well cork borer was used to bore the solidified plates with a diameter of $6 \mathrm{~mm}$. The antibacterial studies were performed with well plates. ${ }^{21}$ 


\section{Antibacterial activity of the lac extracts}

The antibacterial activity of different extracts of lac was performed taking $100 \mu \mathrm{l}$ from the stock solution $(1 \mathrm{mg} / \mathrm{ml})$, were evaluated against E. coli (MTCC-739) and S. aureus (MTCC-3160) by well diffusion method $^{22}$ taking amoxicillin as standard at a concentration of $200 \mu \mathrm{g} / \mathrm{ml}$.

\section{Well diffusion method}

The method used to evaluate the antibacterial activity of different lac extracts was well diffusion. The streak plate method was used for inoculating different stains to the prepared culture plates. Wells of $6 \mathrm{~mm}$ in diameter were made by using sterilized cork well borer. One hundred milliliters from the stock solution $(1 \mathrm{mg} / \mathrm{ml})$ of each extract were seeded in the wells by a sterile syringe. For the optimal bacterial activity plates were incubated for $24 \mathrm{~h}$ at $37^{\circ} \mathrm{C}$. The zone of inhibition around the well was observed. Inhibition was assessed by determining the diameter of the inhibited zone throughout the well $(\mathrm{mm})$ as well as the well diameter. ${ }^{23}$ Readings were taken in three replicates along in three different fixed directions finally, the average values were compiled.

\section{Liquid Chromatography with Mass Spectroscopy}

The instrument used for LC-MS/MS was of Waters ACQUITY FTN Auto-Sampler, QSM series with a quaternary pump system having PDA detector (type UPLC LG $500 \mathrm{~nm}$ ) and ESI detector for MS set at positive ionization mode. The column employed was of reversephase C18, Accucore RPMS $(100 \mathrm{~mm} \times 3 \mathrm{~mm} \times 2.6 \mu \mathrm{m})$ and 3D Channel range $200-450 \mathrm{~nm}$ and resolution of $1.2 \mathrm{~nm}$ whereas compensation reference $2 \mathrm{D}$ parameter ranging from 310-410 $\mathrm{nm}$. The ethyl acetate and methanol fraction were subjected to LCMS/MS using mobile phase, mixture of acetonitrile: water (5:95) in solvent reservoir $\mathrm{A}$, acetonitrile in solvent reservoir $\mathrm{B}$, methanol in solvent reservoir $\mathrm{C}$ and solvent reservoir $\mathrm{D}$ consisted of water + formic acid followed through an effective gradient run (Table 1) at a flow rate of $0.25 \mathrm{ml} / \mathrm{min}$ with a run time of $20 \mathrm{~min}$.

\section{RESULTS}

\section{Assessment of antioxidant activity DPPH scavenging activity}

In the radical scavenging assay, the antioxidant when coming in contact with DPPH there is an occurrence of the color change, the purple color of DPPH changed to yellow. The intense yellow color of DPPH indicates the more prominent antioxidant action of the extract been examined. This is due to the formation of a stable

\begin{tabular}{|c|c|c|c|c|c|}
\hline Time & $\begin{array}{l}\text { Flow } \\
\text { rate }\end{array}$ & $\% A$ & \%B & $\% C$ & \%D \\
\hline Initial & 0.250 & 0.0 & 10.0 & 0.0 & 90.0 \\
\hline 1.00 & 0.250 & 0.0 & 10.0 & 0.0 & 60.0 \\
\hline 6.00 & 0.250 & 0.0 & 40.0 & 0.0 & 40.0 \\
\hline 8.00 & 0.250 & 0.0 & 60.0 & 0.0 & 40.0 \\
\hline 12.00 & 0.250 & 0.0 & 80.0 & 0.0 & 20.0 \\
\hline 14.00 & 0.250 & 0.0 & 80.0 & 0.0 & 20.0 \\
\hline 16.00 & 0.250 & 0.0 & 10.0 & 0.0 & 90.0 \\
\hline 20.00 & 0.250 & 0.0 & 10.0 & 0.0 & 90.0 \\
\hline
\end{tabular}

complex resulting from the reaction between the DPPH and the antioxidant molecule. The standard, ascorbic acid expressed $57.275 \%$ inhibition at a concentration $12 \mu \mathrm{g} / \mathrm{ml}$, while ethyl acetate and methanol showed $54.200 \%$ and $52.350 \%$ inhibition respectively at a concentration $16 \mu \mathrm{g} / \mathrm{ml}$ which is quite promising to that of ascorbic acid. Further extracts (chloroform and aqueous) expressed relatively lower percentage inhibition when compared to standard and test fractions (ethyl acetate and methanol). The percentage inhibition for all extracts along with standard data compiled in Table 2. The results obtained from the DPPH assay for ascorbic acid, ethyl acetate and methanol extracts are quite similar.

\section{Reducing power assay}

The antioxidant compound when tested by reducing power assay, conversion of iron $\left(\mathrm{Fe}^{+3}\right)$ in ferric chloride to ferrous $\left(\mathrm{Fe}^{+2}\right)$ the oxidation form of iron depending upon formation of metal ion complex with iron. This is the basic principle involved in reducing power assay for any antioxidant compounds. In the present study ascorbic acid was taken as standard or positive control. Ascorbic acid showed $54.347 \%$ inhibition at a concentration $12 \mu \mathrm{g} / \mathrm{ml}$, whereas ethyl acetate and methanol showed $52.173 \%$ and $54.347 \%$ inhibition respectively at a concentration $16 \mu \mathrm{g} / \mathrm{ml}$ that is quite promising to that of ascorbic acid. Other extracts (chloroform and aqueous) showed relatively lower percentage inhibition when compared to standard as well as ethyl acetate and methanol extracts. The percentage inhibition of all the extracts and standard data are summarized in Table 3. Ascorbic acid, the reference standard, resembles the activity with that of ethyl acetate and methanol extracts.

\section{Hydrogen peroxide assay}

Hydrogen peroxide is a weak oxidizing agent and highly sensitive to light and at the same time, it can inactivate few of the enzymes by the oxidation of thiol groups. The 


\begin{tabular}{|c|c|c|c|c|c|}
\hline \multicolumn{7}{|c|}{ Table 2: DPPH radical scavenging assay by different extracts of Laccifer lacca. } \\
\begin{tabular}{|c|c|c|c|c|}
\hline \multicolumn{7}{|c|}{ Percentage DPPH inhibition } \\
\hline $\begin{array}{c}\text { Concentration } \\
(\boldsymbol{\mu g} / \mathrm{ml})\end{array}$
\end{tabular} & Ascorbic Acid & Chloroform Extract & Ethyl acetate Extract & Methanol Extract I & Aqueous Extract \\
\hline 4 & 31.475 & 10.900 & 28.075 & 25.525 & 9.475 \\
\hline 8 & 44.975 & 18.475 & 34.700 & 34.248 & 16.975 \\
\hline 12 & 57.275 & 27.225 & 42.575 & 42.475 & 24.950 \\
\hline 16 & 63.900 & 36.425 & 54.200 & 52.350 & 33.050 \\
\hline 20 & 74.700 & 47.150 & 65.050 & 64.825 & 43.975 \\
\hline
\end{tabular}

DPPH: 1, 1-diphenyl-2-picrylhydrazyl

\begin{tabular}{|c|c|c|c|c|c|}
\hline \multicolumn{7}{|c|}{ Table 3: Reducing power assay by different extracts of Laccifer lacca. } \\
\begin{tabular}{|c|c|c|c|c|}
\hline \multicolumn{2}{|c|}{ Percentage reducing power inhibition } \\
\hline $\begin{array}{c}\text { Concentration } \\
(\boldsymbol{\mu g} / \mathrm{ml})\end{array}$
\end{tabular} & Ascorbic Acid & Chloroform Extract & Ethyl acetate Extract & Methanol Extract & Aqueous Extract \\
\hline 4 & 32.609 & 8.696 & 23.913 & 26.087 & 2.174 \\
\hline 8 & 45.652 & 10.870 & 32.609 & 34.783 & 8.696 \\
\hline 12 & 54.348 & 17.391 & 47.826 & 45.652 & 15.217 \\
\hline 16 & 60.870 & 23.913 & 52.174 & 54.348 & 21.739 \\
\hline 20 & 76.087 & 32.609 & 60.870 & 58.696 & 26.087 \\
\hline
\end{tabular}

\begin{tabular}{|c|c|c|c|c|c|}
\hline \multicolumn{6}{|c|}{ Percentage hydrogen peroxide inhibition } \\
\hline $\begin{array}{c}\text { Concentration } \\
(\mu \mathrm{g} / \mathrm{ml})\end{array}$ & Ascorbic Acid & Chloroform Extract & Ethyl acetate Extract & Methanol Extract I & Aqueous Extract \\
\hline 4 & 29.987 & 10.928 & 18.933 & 18.297 & 8.767 \\
\hline 8 & 41.169 & 17.789 & 33.418 & 33.672 & 12.706 \\
\hline 12 & 54.244 & 27.065 & 47.776 & 49.047 & 23.634 \\
\hline 16 & 61.753 & 35.070 & 53.494 & 52.859 & 31.258 \\
\hline 20 & 73.189 & 43.964 & 62.008 & 60.483 & 36.213 \\
\hline
\end{tabular}

present study reveals ethyl acetate and methanol extract exhibits $53.494 \%$ and $52.859 \%$ inhibition respectively at a concentration of $16 \mu \mathrm{g} / \mathrm{ml}$. Ascorbic acid (standard) showed $54.244 \%$ inhibition at a concentration $12 \mu \mathrm{g} / \mathrm{ml}$ which is quite comparable to that of ethyl acetate and methanol extract. While on other hand chloroform and aqueous extract exhibited lower percentage inhibition when compared to standard, ethyl acetate and methanol extracts. The percentage inhibition of all the extracts and standard data are summarized in Table 4. These results proved ethyl acetate and methanol extracts had overall comparable to hydrogen peroxide radical scavenging activity to that of ascorbic acid.

\section{Assessment of antimicrobial activity Antimicrobial activity}

The antimicrobial activity of different extracts of lac was evaluated antibiotic susceptible microorganisms.
The antimicrobial activities of different extracts of lac were studied at a concentration of $(1 \mathrm{mg} / \mathrm{ml})$ taking $100 \mu \mathrm{l}$ solution. Amoxicillin $(200 \mu \mathrm{g} / \mathrm{ml})$ was taken as standard. The antimicrobial activity was assessed in terms of zone of inhibition of bacterial growth for the different extracts of lac. The results and the figures (Figure 1A, 1B, 2A and 2B) are summarized in Table 5. The methanolic and ethyl acetate extract showed $18 \mathrm{~mm}$ zone of inhibition against Escherichia coli (MTCC-739) and $15 \mathrm{~mm}$ against Staphylococcus aureus (MTCC-3160). The present study focused on dose-dependent obtained by a zone of inhibition. The ethyl acetate and methanol extracts of lac showed activity against gram-positive bacteria Staphylococcus aureus and gram-negative bacteria Escherichia coli, at a high concentration of $1000 \mu \mathrm{g} / \mathrm{ml}$. On the other hand, no favorable activity was noted for chloroform and water extract. From the present investigation, it may be suggested that the lac may contain 


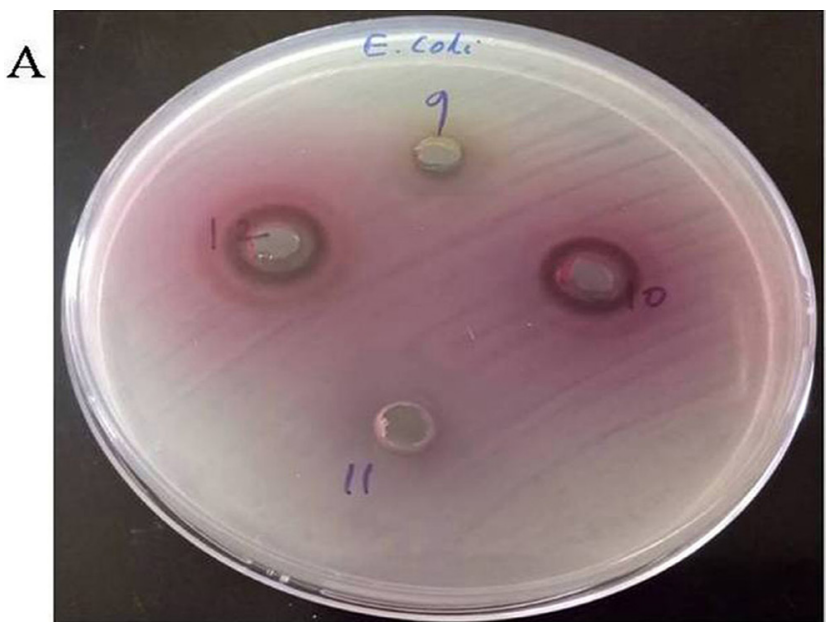

Figure 1A: Zone of inhibition of different extracts (9-Water, 10- Ethyl Acetate, 11- Chloroform and 12- Methanol) of lac dye on E. coli.

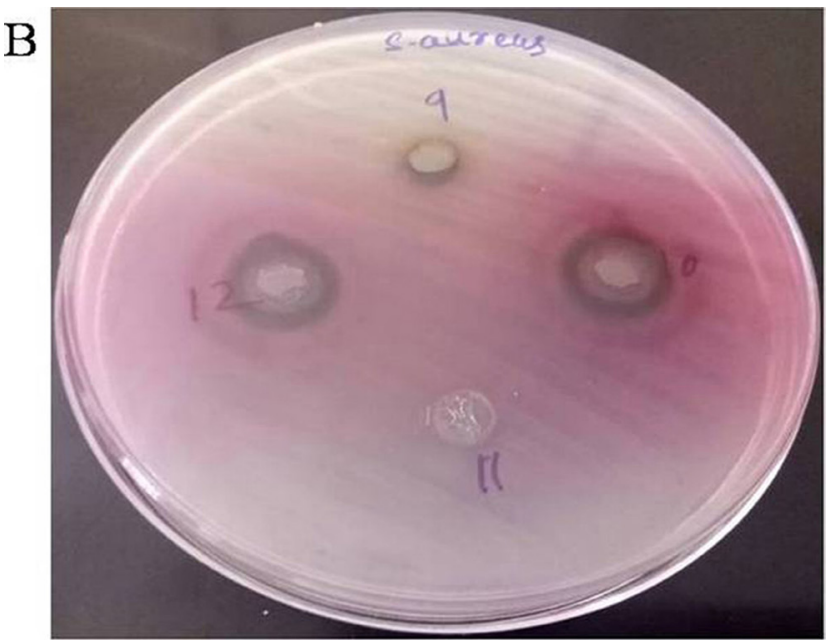

Figure 1B: Zone of inhibition of different extracts (9-Water, 10- Ethyl Acetate, 11- Chloroform and 12- Methanol) of lac dye on S. aureus.

some components or their derivatives such as saponin, triterpenoids, steroids, glycosides, anthraquinones, flavonoids, proteins, amino acids and a phenolic compound may be responsible for possessing antimicrobial activity for ethyl acetate and methanol extracts of lac.

\section{Chromatographic separation of ethyl acetate and methanol fraction using LCMS/MS}

The ethyl acetate and methanol fraction were subjected to LC-MS/MS with an effective gradient run for the identification of active compounds present in these two bio-active fractions with better resolution. Compound having retention time of $1.358 \mathrm{~min}$ (Figure 3) shows an $\mathrm{M}+\mathrm{H}^{+}$prominent peak at $538[\mathrm{M}+\mathrm{H}]^{+}$, other prominent daughter ion peaks of this compound were observed at $519[\mathrm{M}+\mathrm{H}-18]^{+}$for the removal of $\mathrm{H}_{2} \mathrm{O}$

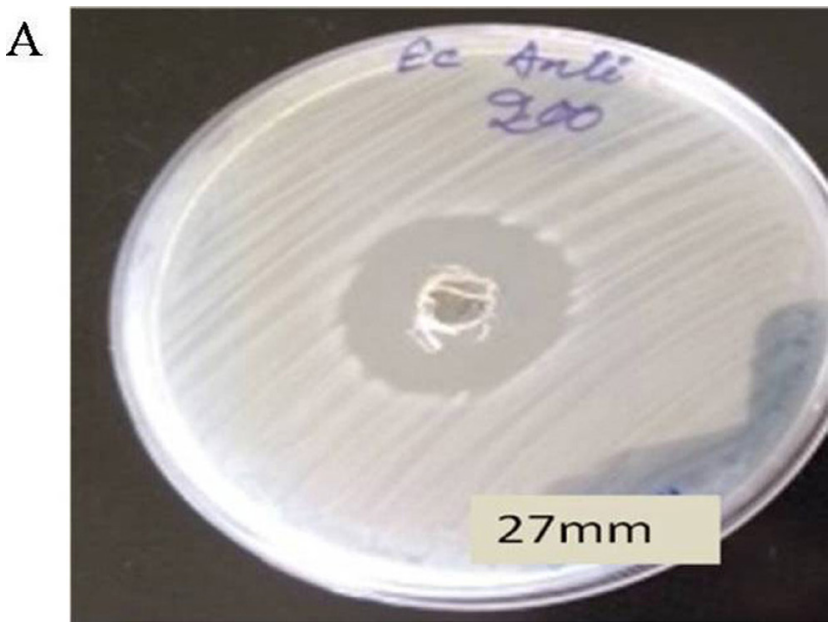

Figure 2A: Zone of inhibition of Amoxicillin (standard) on E. coli.

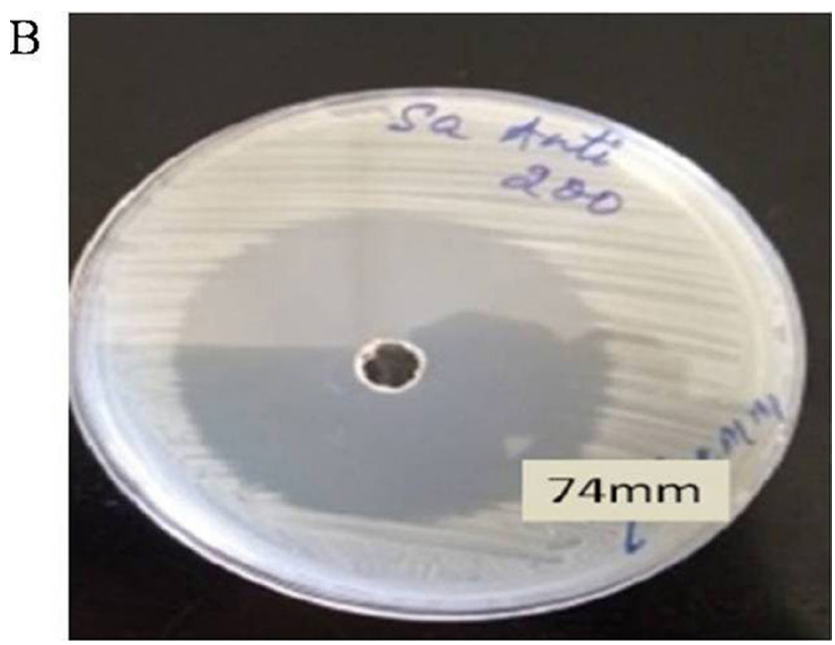

Figure 2B: Zone of inhibition of Amoxicillin (standard) on S. aureus.

and $475[\mathrm{M}+\mathrm{H}-18-44]^{+}$due to the removal of $\mathrm{CO}_{2}$ probably indicating the compound may be laccaic acid A given in Figure 4 and Table 6. The same gradient run was employed for methanol fraction. Retention time of 1.423 min (Figure 5) having ES+ peak at $538[\mathrm{M}+\mathrm{H}]^{+}$ which is as similar to that of the peak present in ethyl acetate fraction along with other daughter ion peaks at $519\left[\mathrm{M}+\mathrm{H}-\mathrm{H}_{2} \mathrm{O}\right]^{+}$and $475\left[\mathrm{M}+\mathrm{H}-\mathrm{H}_{2} \mathrm{O}-\mathrm{CO}_{2}\right]^{+}$identified as same component present in ethyl acetate fraction i.e. laccaic acid $\mathrm{A}$ as identified given in Figure 6 and Table 6. The LC-MS/MS results showed a molecular ion peak of $\mathrm{m} / \mathrm{z} 538[\mathrm{M}+\mathrm{H}]^{+}$for both ethyl acetate and methanol extract which is same molecular mass of laccaic acid A (537amu) with same fragmentation pattern as reported earlier. ${ }^{6,7}$ The structure of laccaic acid-A is given in Figure 7. 


\begin{tabular}{|c|c|c|}
\hline & \multicolumn{2}{|c|}{ Pathogen (zone size in $\mathrm{mm}$ ) } \\
\hline $\begin{array}{c}\text { Stick lac extract } \\
\quad(1 \mathrm{mg} / \mathrm{mL})\end{array}$ & $\begin{array}{c}\text { Staphylococcus } \\
\text { aureus }\end{array}$ & Escherichia coli \\
\hline Chloroform & - & - \\
\hline Ethyl acetate & 18 & 15 \\
\hline Methanol & 18 & 15 \\
\hline Aqueous & - & - \\
\hline $\begin{array}{l}\text { Amoxicillin } \\
\text { (Standard) }\end{array}$ & 74 & 27 \\
\hline
\end{tabular}

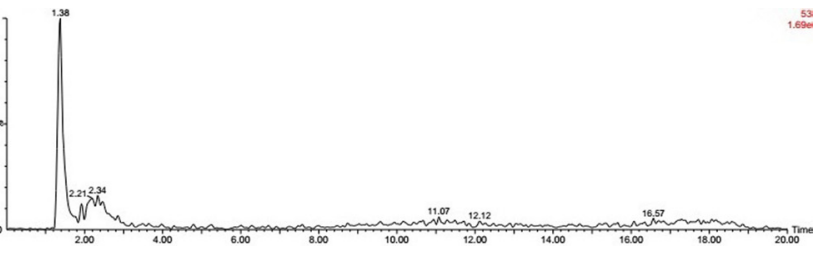

Figure 3: Showing retention time of ethyl acetate extract of lac dye at $1.3 \mathrm{~min}$ on mass chromatograms.

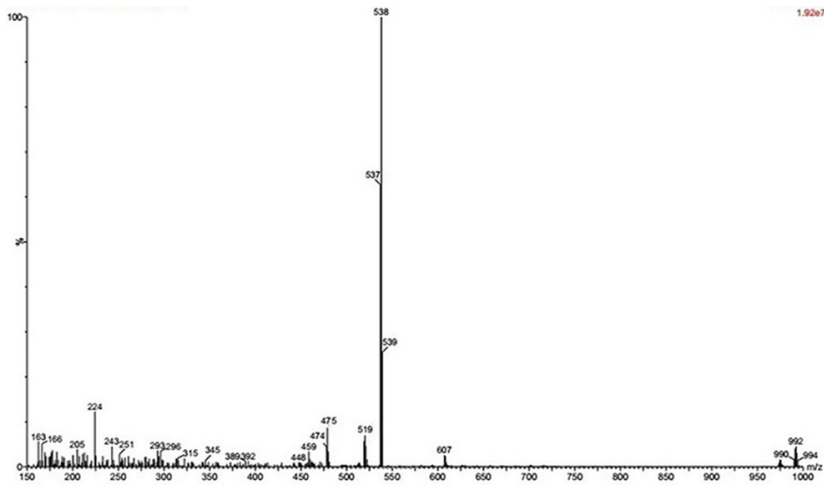

Figure 4: Mass spectrum of ethyl acetate extract with Rt 1.3 and $538 \mathrm{~m} / \mathrm{z}$.

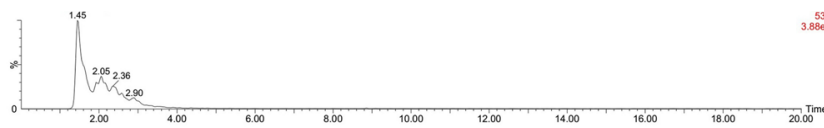

Figure 5: Showing retention time of methanolic extract of lac dye at 1.4 min on mass chromatograms.

\begin{tabular}{|c|c|c|c|c|c|c|}
\hline \multicolumn{7}{|c|}{ Ethyl Acetate fraction of lac dye } \\
\hline \multirow[t]{2}{*}{ SI. No. } & \multirow[t]{2}{*}{$\begin{array}{c}\text { Retention Time } \\
(\text { min) }\end{array}$} & \multirow{2}{*}{$\begin{array}{c}\text { Precursor Ion } \\
{[\mathrm{M}+\mathrm{H}]^{+}} \\
\end{array}$} & \multicolumn{3}{|c|}{ Product Ion } & \multirow[t]{2}{*}{$\begin{array}{l}\text { Compound } \\
\text { Identified }\end{array}$} \\
\hline & & & {$[\mathrm{M}+\mathrm{H}-\mathrm{H}]^{+}$} & {$\left[\mathrm{M}+\mathrm{H}-\mathrm{H}-\mathrm{H}_{2} \mathrm{O}\right]^{+}$} & {$\left[\mathrm{M}+\mathrm{H}-\mathrm{H}-\mathrm{H}_{2} \mathrm{O}-\mathrm{CO}_{2}\right]^{+}$} & \\
\hline 1 & 1.3 & 538 & 537 & 519 & 475 & Laccaic Acid-A \\
\hline 2 & 16.9 & 391 & & & & Unknown \\
\hline \multicolumn{7}{|c|}{ Methanolic fraction of lac dye } \\
\hline \multirow[t]{2}{*}{ SI. No. } & $\begin{array}{l}\text { Retention Time } \\
\text { (min) }\end{array}$ & Precursor lon & \multicolumn{3}{|c|}{ Product Ion } & $\begin{array}{l}\text { Compound } \\
\text { Identified }\end{array}$ \\
\hline & & {$[\mathrm{M}+\mathrm{H}]^{+}$} & {$[\mathrm{M}+\mathrm{H}-\mathrm{H}]^{+}$} & {$\left[\mathrm{M}+\mathrm{H}-\mathrm{H}-\mathrm{H}_{2} \mathrm{O}\right]^{+}$} & {$\left[\mathrm{M}+\mathrm{H}-\mathrm{H}-\mathrm{H}_{2} \mathrm{O}-\mathrm{CO}_{2}\right]^{+}$} & \\
\hline 1 & 1.4 & 538 & 537 & 519 & 475 & Laccaic Acid-A \\
\hline 2 & 8.5 & 515 & & & & Unknown \\
\hline 3 & 11.8 & 269 & & & & Unknown \\
\hline 4 & 15.6 & 452 & & & & Unknown \\
\hline
\end{tabular}

\section{DISCUSSION}

The main focus of the present work is determination of the antimicrobial activity of two different extracts of lac dye, the ethyl acetate and methanolic extract against gram-positive bacteria Staphylococcus aureus and gram-negative bacteria Escherichia coli for the first time, also to identify the active constituent present in the bio-active fraction by LC-MS/MS. The antimicrobial activity of two extracts of lac dye was found to be active at a concentration of $1000 \mu \mathrm{g} / \mathrm{ml}$ having a zone of inhibition of $18 \mathrm{~mm}$ and $15 \mathrm{~mm}$ for Staphylococcus aureus and Escherichia coli respectively. The results obtained showed the antimicrobial activity of both the lac extracts at a high concentration of $1000 \mu \mathrm{g} / \mathrm{ml}$ while the standard drug Amoxicillin at a concentration $200 \mu \mathrm{g} / \mathrm{ml}$ having a zone of inhibition of $74 \mathrm{~mm}$ and $27 \mathrm{~mm}$ for S. aureus and E. coli respectively. Other than antimicrobial activity, the ethyl acetate and methanol extract are also having potent antioxidant activity. The results obtained for ethyl acetate and methanol extract were quite comparable with the standard. Literature suggests that the free radical as well as the reactive oxygen species (ROS) generation can be prevented by the antioxidants available from different natural sources. Antioxidants act by interfering in the oxidation process of the particular substrate. The antioxidant activity or the scavenging 


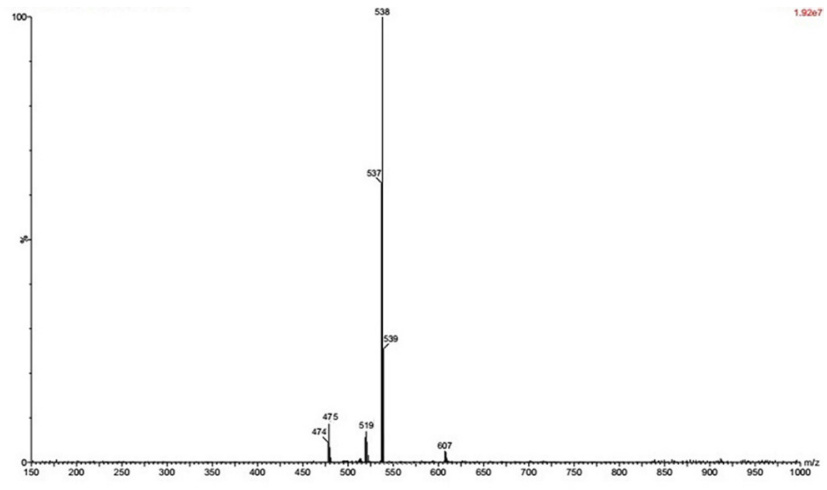

Figure 6: Mass Spectrum of methanolic extract with Rt 1.4 $\min$ and $538 \mathrm{~m} / \mathrm{z}$.

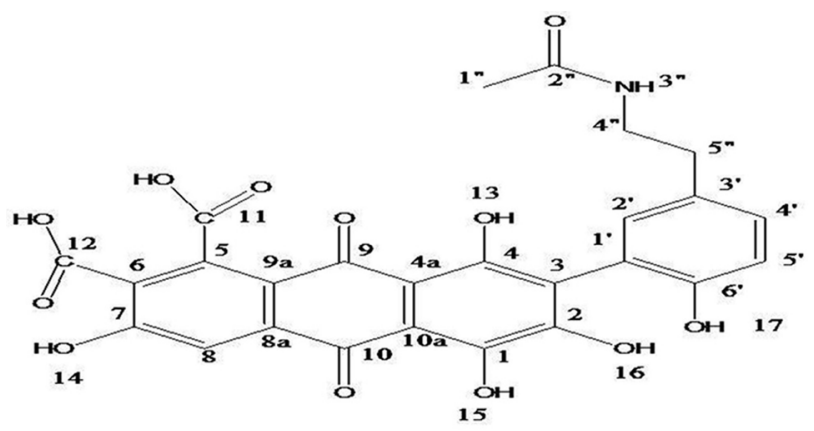

Figure 7: Chemical structure of laccaic acid A.

activity may be the result of the five hydroxyl groups attached to the moiety which may release the $\mathrm{H}^{+}$ion to trap the ROS in the reaction. Both the bioactive extracts were subjected to chromatographic isolation to detect the bioactive moiety responsible for the activity. The ethyl acetate and methanolic extract were subjected to LC-MS/MS which revealed that both the extracts contained prominent $\mathrm{M}+\mathrm{H}^{+}$mass peak at $538[\mathrm{M}+\mathrm{H}]^{+}$. Other prominent peaks were observed at $519[\mathrm{M}+\mathrm{H}-$ $\left.\mathrm{H}_{2} \mathrm{O}\right]^{+}$and $475\left[\mathrm{M}+\mathrm{H}-\mathrm{H}_{2} \mathrm{O}-\mathrm{CO}_{2}\right]^{+}$at retention times 1.358 and 1.423 min for ethyl acetate and methanol indicating the compound to be laccaic acid A. The molecular weight of laccaic acid A (537amu) reported earlier ${ }^{6,7}$ which is same as the molecular mass of the identified compound from ethyl acetate and methanol extract having similar fragmentation pattern. So, laccaic acid A may be the responsible compound for antimicrobial and antioxidant activity.

\section{CONCLUSION}

The above study showed the antimicrobial activity of different extracts of lac dye (ethyl acetate and methanol) for the first time in Staphylococcus aureus and Escherichia coli species with a comparison to a standard. Other than antimicrobial activity both the extracts of lac dye were having a very sound antioxidant activity that to at a very low concentration. Moreover, the two bio-active frac- tions were subjected to LC-MS/MS to identify laccaic acid $\mathrm{A}$ as the main component of the lac dye mainly responsible for the activity.

\section{ACKNOWLEDGEMENT}

The authors would like to thank Sophisticated Analytical Instrument Facility (SAIF- CSIR, Lucknow) for carrying out the LC-MS/MS. We also thank the Indian Council of Agriculture and Research (ICAR) for the financial support (grant no F. No. Agri. Engg. 27(24)/2015-AE dated 20 ${ }^{\text {th }}$ Jan 2016) and Indian Institute of Natural Gums and Resins (IINGR), Ranchi, India for providing the lac dye. Authors are also grateful to the Head, Department of Pharmaceutical Sciences and Technology, Birla Institute of Technology, Mesra, Ranchi, for providing necessary facilities for the research work.

\section{CONFLICT OF INTEREST}

There is no conflict of interest among all authors.

\section{ABBREVIATIONS}

DPPH: 2, 2-diphenyl-1-picrylhydrazyl; LC-MS/MS: Liquid Chromatography-Mass Spectroscopy/ Mass Spectroscopy; E. coli: Escherichia coli; S. aureus: Staphylococcus aureus; ILRI: Indian Lac Research Institute; EC $_{50}$ : Half maximal effective concentration; PHBP: Plasma Hyaluronan-Binding Protein; IC $_{50}$ : Half maximal inhibitory concentration; ESI: Electrospray Ionization; HPLC: High-Performance Liquid Chromatography; PDA: Photodiode Array; IR: Infrared; UVVis: Ultraviolet-Visible; DAD: Diode Array Detector; IINRG: Indian Institute of Natural Resins and Gums; $\mathbf{K}_{3}\left[\mathbf{F e}(\mathbf{C N})_{6}\right]$ : Potassium Ferricyanide; $\mathbf{K H}_{2} \mathbf{P o}_{4}$ : Potassium Dihydrogen Phosphate Buffer or Phosphate Buffer; $\mathbf{F e C l}_{3}$ : Ferric Chloride; rpm: Revolution per minute; C: Chloroform; EA: Ethyl acetate; M: Methanol; W: Water; EtOAc: Ethyl acetate; h: Hour; $\mathbf{H}_{2} \mathbf{O}_{2}$ : Hydrogen Peroxide; CFU: Colony Forming Units; MHA: Muller-Hinton Agar; mm: Millimeter; nm: Nanometer; $\mathbf{H}_{2} \mathbf{O}$ : Water; $\mathbf{C O}_{2}$ : Carbon dioxide; min: Minutes; amu: Atomic Mass Unit; ROS: Reactive Oxygen Species.

\section{REFERENCES}

1. NISCAIR:(http://nsdl.niscair.res.in/jspui/bitstream/123456789/219/1/ LAC\%20CULTURE.pdf Singh R. Lac Culture [online] 2006 [ cited 2016 Sep 5])

2. Wang X, Li JZ, Fan YM, Jin XJ. Present research on the composition and application of lac. For Stud China. 2006;8(1):65-9. 
3. Fagan RL, Cryderman DE, Kopelovich L, Wallrath LL, Brenner C. Laccaic acid $A$ is a direct, DNA-competitive in hibitor of DNA methyltransferase 1. J Biol Chem. 2013;288(33):23858-67.

4. Jimtaisong $\mathrm{A}$, Janthadee $\mathrm{R}$, Nakrit $\mathrm{T}$. In vitro antioxidant activities of laccaic acids and its aluminum lake. Food Sci Biotechnol. 2013;22(4):1055-61.

5. Sekido C, Nishimura N, Takai M, Hasumi K. Inhibition of plasma hyaluronanbinding protein autoactivation by laccaic acid. Biosci Biotechnol Biochem. 2010;74(11):2320-2

6. Oka H, Ito Y, Yamada S, Kagami T, Hayakawa J, Harada KI, et al. Separation of lac dye components by high-speed counter-current chromatography. J Chromatogr A. 1998;813(1):71-7.

7. Oka H, Ito Y, Yamada S, Kagami T, Hayakawa J, Harada K. Identification of lac dye components by electrospray High Performance Liquid Chromatographytandem mass spectrometry. J Mass Spectrom Soc Jpn. 1998;46(1):63-8.

8. Hirata K, Uematsu Y, Suzuki K, lida K, Yasuda K, Saito K. Analysis of main pigments and other ingredients in lac color product. Shokuhin eiseigaku zasshi. Journal of the Food Hygienic Society of Japan. 2001;42(2):109-13.

9. Hirata K, Uematsu Y, Suzuki K, lida K, Kamata K. Analysis of lac color in diets and feces of rats for toxicity studies. Shokuhin eiseigaku zasshi. Journal of the Food Hygienic Society of Japan. 2002;43(2):110-3.

10. Burwood R, Read G, Schofield K, Wright DE. 1133. The pigments of stick lac. Part I. Isolation and preliminary examination. J Chem Soc (Resumed). 1965;6067-73.

11. Burwood R, Read G, Schofield K, Wright DE. The pigments of stick lac. Part II. The structure of laccaic acid A. J Chem Soc. C: Organic. 1967;842-51.

12. Rama RAV, Shaikh IN, Venkataraman K. Laccaic acid C, the first natural anthraquinone with an amino acid side chain. Indian J Chem. 1969;7(2):188-9.

13. Mehandale AR, Rao AR, Shaikh IN, Venkataraman K. Desoxyerythrolaccin and laccaic acid D. Tetrahedron Lett. 1968;9(18):2231-4.

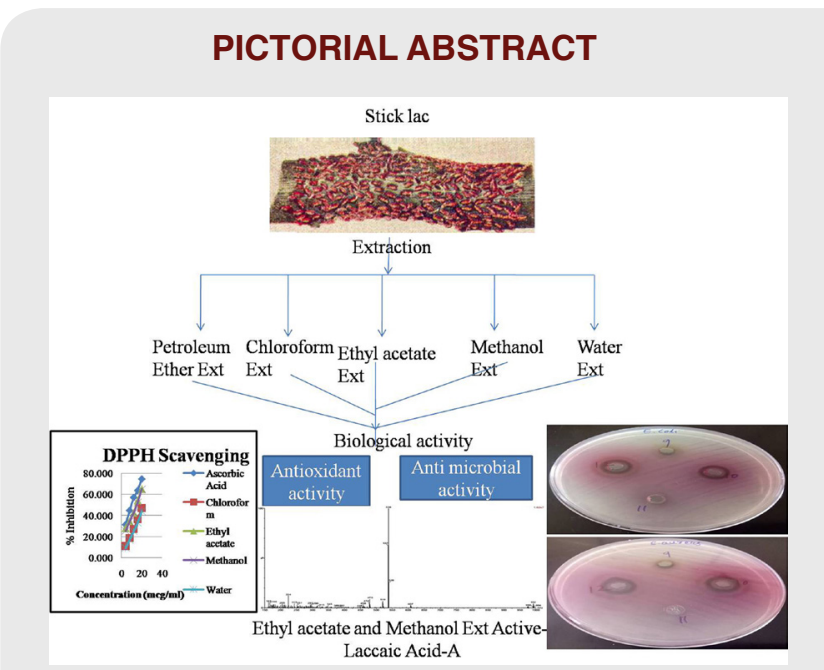

14. Bhide NS, Pandhare ED, Rama RAV, Shaikh IN, Srinivasan R. Lac pigments: Part IV. Constitution of laccaic acid B. Indian J Chem. 1969;7(10):987-95.

15. Santos R, Hallett J, Oliveira MC, Sousa MM, Sarraguça J, Simmonds MS, et al. HPLC-DAD-MS analysis of colorant and resinous components of lac-dye: A comparison between Kerria and Paratachardina genera. Dyes Pigm. 2015;118:129-36.

16. Srivastava S, Ray DP, Pandey SK, Prasad KM, Prasad M, Baboo B. Pure lac dye: A potential natural food additive. IJETAE. 2013;3:589-94.

17. Miliauskas G, Venskutonis PR, Van BTA. Screening of radical scavenging activity of some medicinal and aromatic plant extracts. Food Chem. 2004;85(2):231-7.

18. Jayanthi P, Lalitha P. Reducing power of the solvent extracts of Eichhornia crassipes (Mart.) Solms. Int J Pharm Pharm Sci. 2011;3(3):126-8.

19. Ruch RJ, Cheng SJ, Klaunig JE. Prevention of cytotoxicity and inhibition of intercellular communication by antioxidant catechins isolated from Chinese green tea. Carcinogenesis. 1989;10(6):1003-8.

20. Rios JL, Recio MC. Medicinal plants and antimicrobial activity. J Ethnopharmacol. 2005;100(1-2):80-4.

21. Ahmad I, Beg AZ. Antimicrobial and phytochemical studies on 45 Indian medicinal plants against multi-drug resistant human pathogens. J Ethnopharmacol. 2001;74(2):113-23.

22. Dogruoz N, Karagoz A. Antibacterial activity of some plant extracts. IUFS J Biol. 2008;67(1):17-21.

23. Pathiratna LS, Joseph KD, Perera MK. The effect of some cultural practices on the growth and yield of the medicinal plant Aerva lanata (L). Juss Ex Schult. (Polpala). Ceylon J Sci. 2004;32:67-74.

\section{Summary}

Antioxidant activity of extracts of lac dye was evaluated by three different methods (DPPH, Reducing power and Hydrogen peroxide scavenging) and the results were quit comparable with the standard ascorbic acid. For the first time antimicrobial activity was carried out for different extracts of lac dye against gram-positive bacteria Staphylococcus aureus and gram-negative bacteria Escherichia coli and compared against the standard drug amoxicillin using well diffusion method. The bioactive fraction (ethyl acetate and methanol) was further processed for an effective LC-MS/MS run for the identification of active component (laccaic acid-A) responsible for the activity.

\section{About Authors}

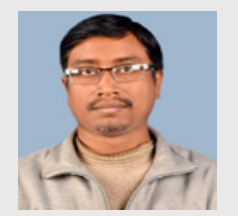

Dr. Manik Ghosh, Assistant Professor, Department of Pharmaceutical Sciences \& Technology, Birla Institute of Technology, Mesra, Ranchi. He has diverse areas of research in the field of Pharmaceutical Chemistry. His work is related to identification of plant extracts having potential antiviral or anticancer activity along with isolation and characterization of phytochemicals. $\mathrm{He}$ is also working in the field of analytical \& bioanalytical chemistry. He has published many research articles in journals of repute.

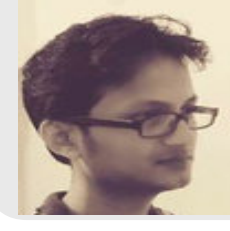

Mr. Suddhasattya Dey, is a Research Scholar from Birla Institute of Technology, Mesra, Ranchi and presently pursuing his Ph.D. under the guidance of Dr. Manik Ghosh. He is recipient of ICAR SRF. He is also working as an Asst. Prof. in Dr. B. C. Roy College of Pharmacy and AHS, Durgapur, West Bengal and presently is on study leave. He is working in the field of phytochemisty and analytical chemistry.

Cite this article: Dey S, Ghosh M. A LC/MS-MS Guided Isolation of Laccaic Acid-A: A Potent Antimicrobial Agent. Indian J of Pharmaceutical Education and Research. 2018;52(4 Suppl 2):S287-S295. 